\title{
The urban logistic service model in the aspect of the domestic logistic system
}

\author{
M. Jacyna \\ Warsaw University of Technology, Faculty of Transport, Poland
}

\begin{abstract}
The paper presents the research effects of the development project entitled "The Model of the Logistic System for Poland as a Way to Transport Comodality in the EU" in relation to the logistic service of a town. Urban agglomeration service models that employ Load Consolidation Centres and Urban Transhipment Hubs are herein presented. The issues of urban logistics in the aspect of the deliveries of goods to customers located within the city borders - with a two-stage service system applied - have been presented as an optimisation task with the service cost minimisation criterion. Proposals for practical applications of the approach are exemplified with a model developed for the Warsaw agglomeration.

Keywords: urban logistics, urban logistic system model, load consolidation centre, urban transhipment hubs.
\end{abstract}

\section{Introduction}

Commercial transport is a factor that intensifies a majority of economic and social activities in urban agglomerations. Supplying shops and places of work and recreation, as well as waste management are also related to this. The transport of goods is, on the other hand, a source of inconvenience for the inhabitants of an urban agglomeration and it impedes their social life.

It appears from the research conducted $[1,2,4,5]$ that urban logistics is aimed, on the one hand, at reducing the inconvenience related to the transport of goods in urban agglomeration areas and, on the other hand, at supporting the economic and social development of those agglomerations. The studies in the field urban of logistics are primarily focused on finding solutions enabling the reduction of goods traffic in towns. 
One of the possible solutions consists in providing service to urban agglomerations within the framework of the so called urban integrated logistic system (UILS). The employment of UILS in the movement of materials is aimed at reducing goods traffic in the urban area through the coordination of those movements and the elimination of empty runs. Another goal is the reduction of the nuisance related to the supplies of goods to a wide range of customers (entities) located in the urban area. In the project carried out at the Logistics and Transport Systems Unit of the Warsaw University of Technology as part of the UILS, it has been proposed that transitional transhipment points, the so called Load Consolidation Centres (LCC) should be employed and in heavily urbanised areas, they should be supplemented with Urban Transhipment Hubs (UTH).

\section{Urban agglomeration service systems}

\subsection{General assumptions}

Spatial structures of towns are very different and may assume various forms, e.g. those of concentric, sectoral or star-shaped models. In addition, multifocal models can be identified as having combined features of both sectoral models and star-shaped ones. It has a direct impact on transport planning and the demarcation of service regions and, in consequence, on the provision of transport services in a particular region and for a particular group of customers in the town.

The basic aim of urban logistics, from the point of view of goods transport assurance, is alleviation and resolving conflicts resulting from deliveries of goods to the urban area $[8,9,11-13]$. In view of the scarcity of space and limited feasibility of urban infrastructure extension, it becomes more and more difficult to meet the basic logistic requirements as regards the service provision time. Bearing in mind the $7 \mathrm{P}$ principle (proper product, quantity, time, condition, place, customer and cost), the assurance of the deliveries of goods to dispersed customers should be considered not only in the time dimension, but in the spatial and cost dimensions, as well.

The primary limitation of a proper service provision to the urban agglomeration is an inefficient, in general, urban infrastructure. One of consequences of maladjustment of both linear and punctual infrastructures to temporary requirements in respect of movements of loads and people in urban areas is traffic congestion [3].

In view of the above, one can say that urban logistics is the movement of loads and the streams of information related to those movements from the places of origin (shipment) to the places of receipt for the purpose of providing urban users (inhabitants) with access to goods. The identification of traffic sources allows the load movement structure to be set and creates conditions for taking actions aimed at improving the movements and identifying critical points which significantly affect the quality of the transport services provided. The driving force behind the urban logistics is above all the need to overcome congestions. 


\subsection{The load consolidation centre and urban transhipment hubs in the urban agglomeration service}

The time and quality requirements for the urban agglomeration service necessitate some actions aimed at improving the distribution process in urban areas. As we have already mentioned in section 1, such improvements can be introduced through the application of the so-called Load Consolidation Centres and Urban Transhipment Hubs. The project assumes that the LCC is a link connecting elements of the Domestic Logistic System (DLS) with the Urban Logistic System (ULS) (Fig. 1), [1, 2].

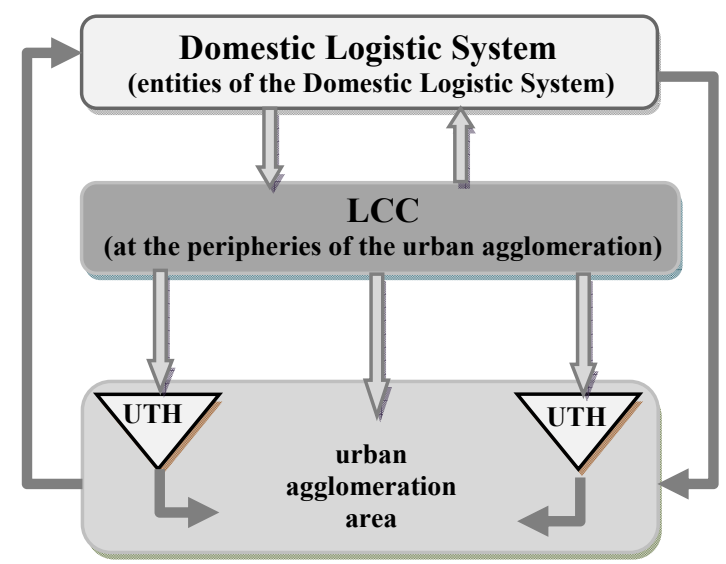

Source: Drawn up by the author on the basis of [2].

Figure 1: Impact of the DLS environment on the ULS.

It has been assumed that the LCC provides, as an independent business entity, logistic services, including, among others, transport, transhipments, storage, distribution and the commissioning of goods originating from the ULS environment. It thereby performs supply and distribution functions in favour of customers situated in the urban agglomeration area. Hence, the LCC is a logistic entity of a storage type, i.e. a buffer-distribution-marshalling entity characterised by a very high rotation and differentiated types of material streams.

Goods supply points in urban agglomerations include production branch houses, retail outlets (shopping centres, specialised shops, shopping galleries, etc.), service and trade type establishments, etc. Customers may be served in the following manners [12]:

- direct - direct supplies from the goods consigner from areas surroundings the town to the recipient located in the urban agglomeration area,

- indirect - through Load Consolidation Centres and Urban Transhipment Hubs,

- mixed - directly or with participation of an LCC or a UTH. 
In the case of the direct service, we have a single stage movement of goods between product manufacture points and supply points. It means that the movement is continuous and not disturbed by transhipment and storage operations. Goods are carried directly with proper transport means to the recipient located in the urban area (Fig. 2a).

In the case of the direct or mixed service, a significant role is played by Load Consolidation Centres (LCC). Considering the number of intermediate stages occurring in the urban logistic service with the so-called load service points applied, two types of customer services can be distinguished: a single-stage service and a two-stage one.

In the case of the single-stage service, the merchandise is delivered with hightonnage transport means to the LCC where loads are submitted to distribution and marshalling processes. Once the transport plan is prepared, the goods are loaded on lower capacity vehicles and delivered to recipients in the urban area, e.g. to retail outlets, etc. In this case, transport is interrupted in order to reduce the number of large trucks running within the town's borders (Fig. 2b).

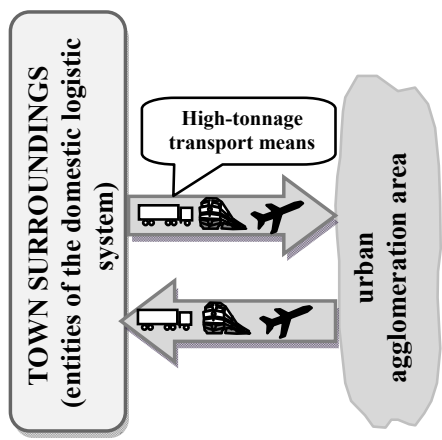

a)

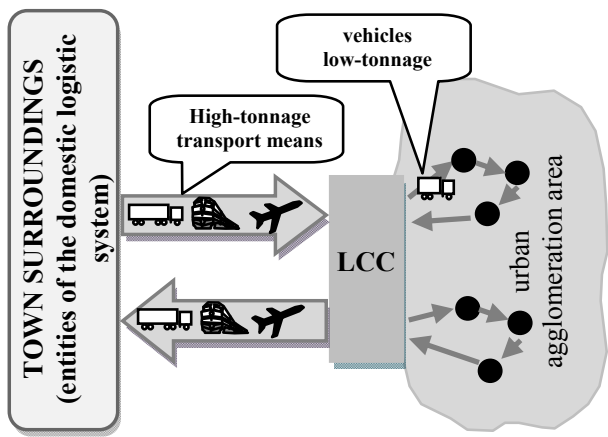

b)

Source: Prepared by the author.

Figure 2: Graphic illustration of town service types: a) direct service b) indirect service with the use of the LCC.

When more than one transition point occurs in the urban logistic service, we have a two-stage goods supply system (Fig. 3). Apart from the LCC, additional transitional points occur, i.e. the so called Urban Transhipment Hubs (UTH). Such a service is reasonable in the case of large cities characterised by a high population density level and a large number of trade, administration and cultural facilities, where the distance from the LCC situated at the city outskirts to the centre is large. When the town has more than one LCC, then the urban area is divided into regions and each of the LCCs serves its own area. In this case, the merchandise loaded at the LCC is not brought directly to customers but to UTHs located in different city zones, where the assortment is distributed and the transport means is replaced with a smaller commercial vehicle (Fig. 3a).

Urban agglomeration service models also include mixed models originating from the combination of one- and two-stage service systems. These models 
admit the possibility of direct service in some justified cases. A graphic illustration of the urban logistic service with a mixed goods supply system is presented in Fig. $3 b$.
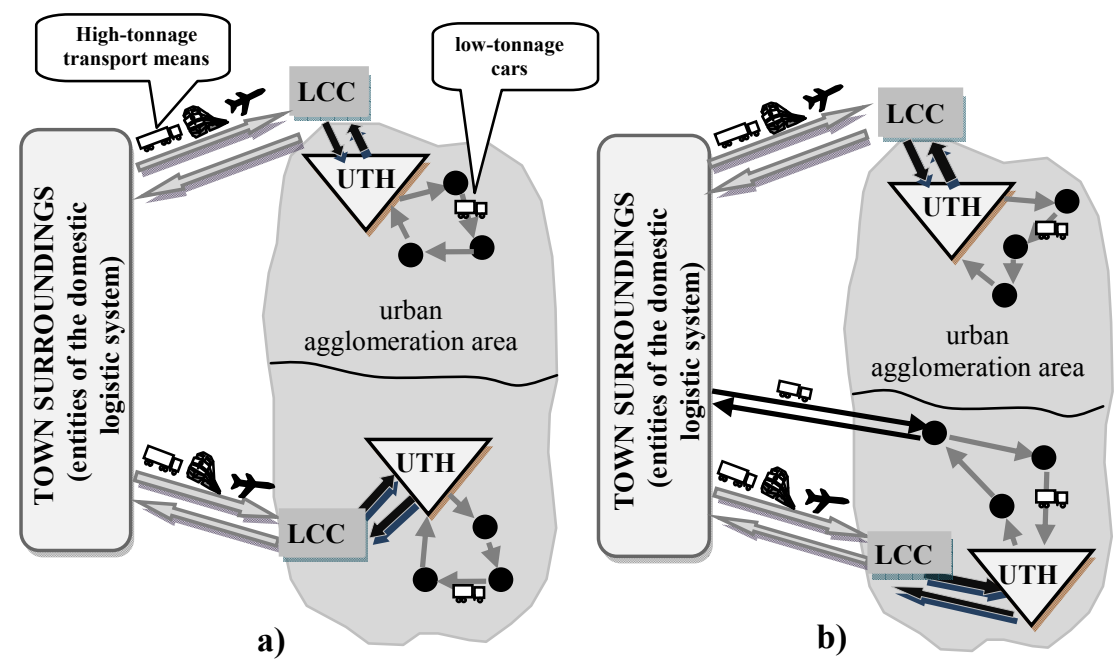

Source: Prepared by the author.

Figure 3: Graphic illustration of the urban logistic service model a) two-stage service system b) mixed service system.

\section{Urban logistic service model in relation with the DLS}

\subsection{General assumptions}

The literature on urban logistics issues $[1-3,7,8]$ is very rich and primarily concerns the solutions aimed at satisfying the expectations of a group of customers very differentiated in respect of their needs, as well as the methods of reduction of the truck traffic arduousness in towns. As it has already been said, the logistic service of urban agglomerations is a very complicated problem due to the high population density and the broad spectrum of consumers, which results in overloading the road network and worsening the condition of urban roads. Another consequence is limitations in the transport infrastructure development.

Improvement in the urban transport service primarily means a reduction of commercial vehicles in the urban area. Such a reduction can be achieved, among other things, through a more effective usage of vehicles, e.g. by obtaining higher average vehicle loading coefficients, reducing empty runs, etc. [2-4]. The issue of the urban area service is related to servicing disperse customers located in heavily urbanised areas. Therefore, it pertains to the problem of setting transport routes as part of the so called Vehicle Routing Problem (VRP). 
The paper presents the model of a two-stage urban logistic service system. Transition points in the system are Load Consolidation Centres (LCC) and Urban Transhipment Hubs (UTH). It has been assumed that the logistic service proceeds in the following manner:

1) goods are delivered with high tonnage transport means (urban motor trucks, UMT) to LCCs where the goods are unloaded. The goods come from various sources, including production companies and wholesale agents belonging to Poland's Logistic System;

2) at the LCC, goods are sorted, possibly consolidated and loaded on the socalled urban motor trucks (UMT) with a capacity of up to 10 tons;

3) for each UMT type vehicles, the departure time and service routes are set; each vehicle serves one or more UTHs;

4) at the UTH, the merchandise is reloaded to delivery vehicles (urban delivery vans, UDV, with a maximum capacity of up to 3.5 tons;

5) delivery vans (UDV) supply indicated customers along set routes and then go to the point where another loading takes place (it is not necessarily the same UTH). When the vehicle goes back to the same hub then the route is determined according to the Travelling Salesman Algorithm.

The urban agglomeration is divided into zones defined as service regions of respective UTHs. The routes where UMT and UDV type vehicles travel have been specially selected to facilitate the access to transhipment points and reduce the impact on the urban transport system and the environment.

The system operation period is described by period set $\boldsymbol{T}$, i.e.

$\boldsymbol{T}=\{t: t=1,2, \ldots, \bar{T}\}$. It is assumed that the planning horizon is relatively short - a few hours or half a day in most cases.

We also assume that the journey time is strictly related to traffic conditions, hence it may change in a period of time and in a particular urban zone (e.g. traffic jams moving towards the city centre during the morning rush hour, etc.). Moreover, depending on a specific time of day, possible passage routes between two points in the town may differ as a result of traffic regulations or restrictions introduced for congested urban areas.

\subsection{Description of the data to be introduced to the model}

The developed model serves the purpose of minimising the number of vehicles in the town, especially urban motor trucks, with the conditions met as regards satisfying the recipients' needs (the order may not be divided between various routes). The data to be verified concern:

- transhipment points LCC and UTH and their work specificity;

- types and characteristics of the vehicles employed for the service;

- customers' needs;

- times of servicing individual points and customers, depending on the type of service provided.

We assume that there are set characteristics of each of the transition points, i.e. LCC and UTH in respect of the working hours and service capabilities of 
urban motor trucks and urban delivery vans. Therefore, we assume that the following has been defined:

- set $\boldsymbol{C K}=\left\{L C_{c k}: c k=1,2, \ldots, \overline{C K}\right\}$ - numbers of the Load Consolidation Centres where the goods are sorted and consolidated;

- set $\boldsymbol{H P}=\{h p: h p=1,2, \ldots, \overline{H P}\}$ - numbers of UTH points;

- set $S^{C}=\{s: s=1,2, \ldots, \bar{S}\}$, types of urban motor trucks (UMT) that are to transport goods from LCCs to UTHs;

- number of type $S$ UMT vehicles marked as value $n(s) \in N$;

- capacity of type $S$ UMT vehicles marked as value $\alpha(s) \in R^{+}$;

- set $\boldsymbol{M D}=\{d: d=1, \ldots, \bar{D}\}$ - types of urban delivery vans (UDV) that are to transport goods from the UTH directly to customers;

- number of type $d$ UDVs marked as value $n(d) \in N$;

- capacity of type $d$ UDV vehicles marked as value $\alpha 1(d) \in R^{+}$;

- set $\boldsymbol{U}=\left\{u(s): u(s)=1, \ldots, \overline{U(s)\}}\right.$ services provided by the $s^{\text {th }}$ urban motor trucks;

- set $\boldsymbol{U} \boldsymbol{d}=\left\{u d(d): u d(d)=1, \ldots, \overline{U d(d)\}}\right.$ services provided by the $d^{\text {th }}$ urban delivery vans;

- unit $\operatorname{cost} k(u(s), s) \in R^{+}$of performing service $u(s)$ by vehicle $s$,

- unit cost $k 1(u d(d), d) \in R^{+}$of performing service $u d(d)$ by vehicle $d$;

- time $\tau c(u(s), s) \in R^{+} \cup\{0\}$ needed for unloading of type $s$ UMT vehicles at the $h p^{\text {th }}$ transhipment hub;

- time $\tau d(u d(d), d) \in R^{+} \cup\{0\}$ needed for unloading of type $d$ UDV vehicles at the $h p^{\text {th }}$ transhipment hub;

- maximum number of UMTs served simultaneously at the UTH, marked as $n^{c}(h p, s) \in N$;

- maximum number of UDVs served simultaneously at the UTH, marked as $n^{d}(h p, d) \in N$;

Most of the customers are business entities with known characteristics so we assume that we have:

- a set of $\boldsymbol{J}=\{1,2, \ldots, i, j, \ldots . \overline{J\}}$ numbers of customers served by the distribution system designed;

- set of $\boldsymbol{L}^{j}=\left\{l: l=1,2, \overline{L^{j}}\right\}$ types of goods delivered to the $j^{\text {th }}$ customer from the LCC;

- set of $\boldsymbol{L}^{h p}=\left\{l: l=1,2, \overline{L^{h p}}\right\}$ types of goods delivered to the $h p^{\text {th }} \mathrm{UTH}$;

- vector $\mathbf{z}^{l}=[q(l, 1), \ldots, q(l, j), \ldots, q(l, \bar{J}]$ of customers' potential orders for $l$ type goods;

- values $q(l, j)$ with the interpretation of the volume of the order for the $l^{\text {th }}$ type of merchandise at the $j^{\text {th }}$ customer; 
- values $q(l, h p)$ with the interpretation of the volume of the order for the $l^{\text {th }}$ type merchandise at the $h p^{\text {th }}$ hub;

- value $\left[t^{a}(j), t^{b}(j)\right]$ with the interpretation of the time interval in which the carriage to the $j^{\text {th }}$ customer is to be executed;

- value $t(j) \in \boldsymbol{T}$ with the interpretation of the time interval number $t$ in which the order of the $j^{\text {th }}$ customer is to be executed;

- value $\tau^{j}(l, j, d) \in R^{+} \cup\{0\}$ with the interpretation of the time needed for unloading the $d^{\text {th }}$ vehicle with the $l^{\text {th }}$ merchandise at the $j^{\text {th }}$ customer.

The planning includes, in most cases, from several hours to half a day, so each period should also be relatively short, e.g. of the order of a quarter or half an hour. It has been assumed at the same time that in the period not more than one departure of the $s^{\text {th }}$ vehicle to the UTH may occur and the period length is a multiple of the unloading time of a UMT type vehicle.

\subsection{Service model record formalisation}

The urban logistic service model presented in this paper is a result of the work on the development project [10] and it is also patterned after the work [8]. Generally, the problem of the urban logistic service can be recorded as follows. For assigned sets $\boldsymbol{C K}, \boldsymbol{H P}, \boldsymbol{J}$ and the sets of characteristics of transport means $\mathbf{S}^{\mathbf{c}}$, $\boldsymbol{M D}, \boldsymbol{U}, \boldsymbol{U d}$, as well as the sets of characteristics of transition points, the following must be determined:

$$
\begin{gathered}
\forall u(s) \in \boldsymbol{U} x(u(s))= \begin{cases}1 & \text { when an urban motor truck provides type } u(s) \text { service } \\
0 & \text { in other cases }\end{cases} \\
\forall u d(d) \in \boldsymbol{U d} y(u d(d))= \begin{cases}1 & \text { when an urban delivery van provides type ud }(d) \\
0 & \text { in other cases }\end{cases}
\end{gathered}
$$

while taking into account, among other things, limitations related to:

- non-exceeding of the load capacity of $s$ type vehicles in a single course

$$
\forall u(s) \in \boldsymbol{U} \sum_{l \in \boldsymbol{L}^{h p}} \sum_{h p \in \boldsymbol{H}^{*}} \boldsymbol{q}(\boldsymbol{l}, \boldsymbol{h p}) \leq \alpha(\boldsymbol{s}) \boldsymbol{x}(\boldsymbol{u}(\boldsymbol{s}))
$$

where $\boldsymbol{H P}^{*}$ is the set of hubs served at the particular course

— non-exceeding of the load capacity of type $d$ urban motor vehicles

$$
\forall u d(d) \in \boldsymbol{U d} \sum_{\boldsymbol{l} \in \boldsymbol{L}^{j}} \sum_{\boldsymbol{j} \in \boldsymbol{J}^{*}} \boldsymbol{q}(\boldsymbol{l}, \boldsymbol{j}) \leq \alpha 1(\boldsymbol{d}) \boldsymbol{y}(\boldsymbol{u d}(\boldsymbol{d}))
$$

where $J^{*}$ is the set of recipients served at the particular course

- the work of urban transhipment hubs and the condition of non-exceeding the transhipment capacities in a specified time interval: 
○ in the case of urban motor trucks of the $s$ type

$$
\forall h p \in \boldsymbol{H P} \forall t \in \boldsymbol{T} \sum_{\boldsymbol{t}^{*}=\boldsymbol{t}-\tau \boldsymbol{c}(\boldsymbol{s})+1}^{\boldsymbol{t}} \sum_{\boldsymbol{u}(\boldsymbol{s}) \in \boldsymbol{U}}(\boldsymbol{u}(\boldsymbol{s})) \leq \boldsymbol{n c}(\boldsymbol{h p}, \boldsymbol{s})
$$

○ in the case of urban delivery vans of the $d$ type

$$
\forall h p \in \boldsymbol{H P} \forall t \in \boldsymbol{T} \sum_{\boldsymbol{t}^{*}=\boldsymbol{t}-\tau \boldsymbol{d}(\boldsymbol{d})+1}^{\boldsymbol{t}} \sum_{\boldsymbol{u}(\boldsymbol{s}) \in \boldsymbol{U}} \boldsymbol{y}(\boldsymbol{u d}(\boldsymbol{d})) \leq \boldsymbol{n d}(\boldsymbol{h p}, \boldsymbol{d})
$$

- limitation to the number of $s$ type vehicles owned

$$
\forall s \in S^{c} \quad \sum_{u(s) \in U} \boldsymbol{x}(\boldsymbol{u}(s)) \leq \boldsymbol{n}(\boldsymbol{s})
$$

- limitation to the number of $d$ type vehicles owned

$$
\forall d \in M D \sum_{u d(d) \in U d} y(u d(d)) \leq n(d)
$$

so that the function of criterion of the interpretation of the total system operation cost being a total of the costs generated by UDV vehicles of the $s$ type and UMT vehicles of the $d$ type

$$
\left[\sum_{s \in S^{c}} \sum_{u d(d) \in U d} k(u(s), s) x(u(s))+\sum_{d \in M D} \sum_{u d(d) \in U d} k 1(u d(d), d) y(u d(d))\right]
$$

achieved the minimum value.

\subsection{Case study exemplified by the Warsaw agglomeration}

The case study is related to the optimisation of the provision of refreshing drinks from different suppliers of shops located in Warsaw. It has been assumed that the Load Consolidation Centres for this merchandise are located in the outskirts of the city, at main exit roads to the north, south, east and west. The merchandise is delivered from the LCC to UTHs located in each of the 17 Warsaw districts. The deployment of LCCs and UTHs is presented in Fig. 4. The optimisation was made for two time horizons (2 optimisation variants) with a changing number of recipients in a particular district.

Variant 1 assumes an improvement in the routes currently applied. Then in variant 2 , the number of the goods recipients was increased from 15 to 20 shops. Due to the volume of the input data related to the number of recipients, the optimisation results are presented only for one district (Wawer). It has been assumed that the UTH for the district is supplied every day by LCC3 (see Fig. 4a.) [14].

The costs of the current transport service, resulting mainly from the number of vehicles used for delivery and the total length of the routes covered by them, 


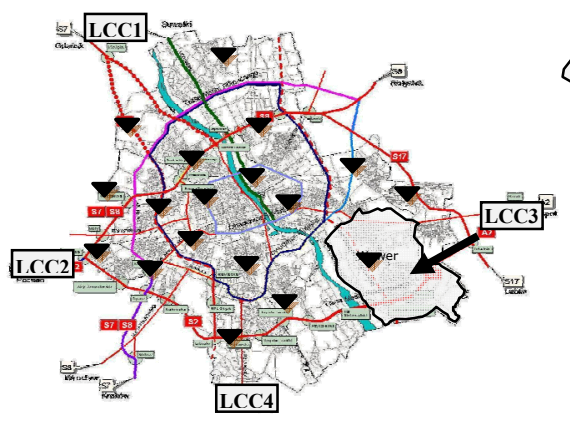

WARSAW

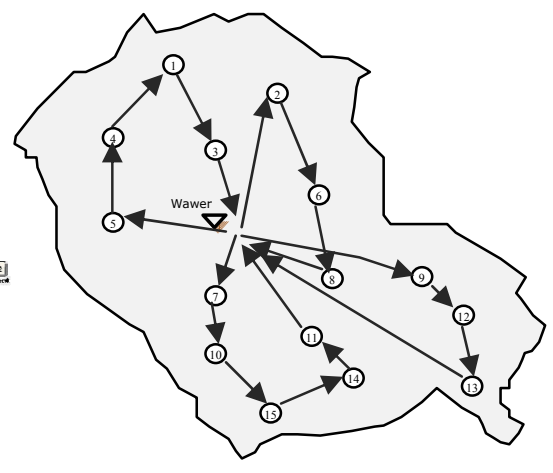

b

Figure 4: Graphic illustration of a) the transport service region, and b) the current structure of the routes operated by the transport company. Source: Prepared by the author.

have been compared with the same data obtained from the optimisation. Additionally, for each variant, the costs of the monthly service of the region have been calculated with the assumption of a 6-day working week.

The data related to the currently operated routes for the transport service of shops in the Wawer district are presented in Table 1.

Optimisation results for variants 1 and 2 are presented in Tables 2 and 3.

Table 1: Data related to the currently operated routes for the transport service of shops in the Wawer district.

\begin{tabular}{cccccccc}
\hline $\begin{array}{c}\text { vehicle } \\
\text { no. }\end{array}$ & $\begin{array}{c}\text { route } \\
\text { length } \\
{[\mathbf{k m}]}\end{array}$ & $\begin{array}{c}\text { on-route } \\
\text { ride time } \\
{[\mathbf{m i n}]}\end{array}$ & $\begin{array}{c}\text { unloading } \\
\text { time } \\
\text { [min] }\end{array}$ & $\begin{array}{c}\text { total route } \\
\text { covering } \\
\text { time [min] }\end{array}$ & $\begin{array}{c}\text { vehicle } \\
\text { use } \\
{[\%]}\end{array}$ & $\begin{array}{c}\text { cost } \\
\text { [Euro] }\end{array}$ & $\begin{array}{c}\text { monthly cost } \\
\text { [Euro] }\end{array}$ \\
\hline $\mathbf{1}$ & 18.9 & 37 & 29 & 66 & 97 & 3.4 & 85 \\
$\mathbf{2}$ & 15.7 & 31 & 25 & 56 & 70 & 2.8 & 70 \\
$\mathbf{3}$ & 18 & 36 & 30 & 66 & 99 & 3.2 & 80 \\
$\mathbf{4}$ & 22.1 & 44 & 28 & 72 & 98 & 3.9 & 97.5 \\
Total & 74.7 & 148 & 112 & 260 & avg-91 & 13.3 & 332.5 \\
\hline
\end{tabular}

Source: Prepared by the author.

Table 2: Variant 1 of transport service optimisation for the Wawer district region.

\begin{tabular}{cccccccc}
\hline $\begin{array}{c}\text { vehicle } \\
\text { no. }\end{array}$ & $\begin{array}{c}\text { route } \\
\text { length } \\
{[\mathbf{k m}]}\end{array}$ & $\begin{array}{c}\text { on-route } \\
\text { ride time } \\
{[\mathbf{m i n}]}\end{array}$ & $\begin{array}{c}\text { unloading } \\
\text { time } \\
{[\mathbf{m i n}]}\end{array}$ & $\begin{array}{c}\text { total route } \\
\text { covering } \\
\text { time [min] }\end{array}$ & $\begin{array}{c}\text { vehicle } \\
\text { use } \\
{[\%]}\end{array}$ & $\begin{array}{c}\text { cost } \\
\text { [Euro] }\end{array}$ & $\begin{array}{c}\text { monthly cost } \\
\text { [Euro] }\end{array}$ \\
\hline $\mathbf{1}$ & 17.4 & 34 & 30 & 64 & 98 & 3.1 & 77.5 \\
$\mathbf{2}$ & 16.1 & 32 & 22 & 54 & 71 & 2.8 & 70 \\
$\mathbf{3}$ & 17.8 & 35 & 30 & 65 & 97 & 3.2 & 80 \\
$\mathbf{4}$ & 20.8 & 42 & 30 & 72 & 98 & 3.7 & 92.5 \\
Total & 72.1 & 143 & 112 & 255 & avg-91 & 12.8 & 320 \\
\hline
\end{tabular}


Source: Prepared by the author.

Table 3: Variant 2 of transport service optimisation for the Wawer district region.

\begin{tabular}{cccccccc}
\hline $\begin{array}{c}\text { vehicle } \\
\text { no. }\end{array}$ & $\begin{array}{c}\text { route } \\
\text { length } \\
{[\mathbf{k m}]}\end{array}$ & $\begin{array}{c}\text { on-route } \\
\text { ride time } \\
{[\mathbf{m i n}]}\end{array}$ & $\begin{array}{c}\text { unloading } \\
\text { time } \\
{[\mathbf{m i n}]}\end{array}$ & $\begin{array}{c}\text { total route } \\
\text { covering } \\
\text { time [min] }\end{array}$ & $\begin{array}{c}\text { vehicle } \\
\text { use } \\
{[\%]}\end{array}$ & $\begin{array}{c}\text { cost } \\
{[\text { [Euro] }}\end{array}$ & $\begin{array}{c}\text { monthly cost } \\
\text { [Euro] }\end{array}$ \\
\hline $\mathbf{1}$ & 13.2 & 26 & 29 & 55 & 98 & 2.3 & 57.5 \\
$\mathbf{2}$ & 14.3 & 28 & 27 & 55 & 86 & 2.5 & 62.5 \\
$\mathbf{3}$ & 15.6 & 31 & 28 & 59 & 97 & 2.8 & 70 \\
$\mathbf{4}$ & 17.9 & 35 & 28 & 63 & 97 & 3.2 & 80 \\
$\mathbf{5}$ & 13.9 & 27 & 27 & 54 & 96 & 2.5 & 62.5 \\
$\mathbf{6}$ & 14.5 & 29 & 30 & 59 & 98 & 2.6 & 65 \\
Total & 89.4 & 176 & 169 & 345 & avg-95 & 15.9 & 397.5 \\
\hline
\end{tabular}

Source: Prepared by the author.

\section{Conclusions}

The Integrated Urban Logistic System for the goods service with the application of Load Consolidation Centres has a significant impact on setting in order the movements of goods between the environment and recipients located within the urban agglomeration area. It follows from the research carried out as part of the project that the application of the solutions improving the movements of goods in towns as based on the two-stage urban service system with the use of LCCs and UTHs brings about, among other things:

- lower road congestion in the intercity traffic,

- slower deterioration of roads and road infrastructure,

- reduction of transport congestion in city centres,

- reduction of excessive emission of exhaust gas and other pollutions related to vehicle exploitation.

The above model represents a general approach to the urban logistic service as regards the deliveries of goods to scattered customers. As we have proved, the choice of transport means that are suitable for the routes is extremely important. Further works are aimed at developing an integrated decision support system in the field of servicing customers dispersed in urban agglomeration areas, while taking into consideration the limitations resulting from insufficient time resources and transport means.

\section{Acknowledgements}

The paper is a result of the work conducted as part of the development grant entitled "A logistic System for Poland as a Way to Transport Comodality in the European Union". The project is funded by the National Centre for Research and Development. No. R10 0027 06/2009. Project Manager - Marianna Jacyna. 


\section{References}

[1] Bluszcz M., Jacyna M.: Modelowa struktura miejskiego sytemu logistycznego. [A Model Structure of the Urban Logistic System], Logistyka, Poznań, 4/2009.

[2] Bluszcz M., Jacyna M.: Model Solutions for Interfaces of the Urban Logistic System with the Domestic Logistic System, Archives of Transport, Polish Academy of Sciences Committee of Transport, Warsaw,volume21, pp. 5-24, 2009.

[3] Browne M., Allen S. and Woodbum: Urban Freight Consolidation Centres. In Taniguchi E. And Thompson R.G. editors. Recent Advances in City Logistics. Elsevier, Amsterdam, pp.253-265, 2006.

[4] Chmielewski J.M.: Teoria urbanistyki w projektowaniu i planowaniu miast [Theory of Town Planning in Designing and Planning of Towns], Oficyna Wydawnicza Politechniki Warszawskiej, Warszawa 2001.

[5] Crainic, T.G., Ricciardi, N., Storchi, G. Models for Evaluating and Planning City Logistics Transportation Systems. CIRRELT-2007.

[6] Hoyt, H., 1939: The Structure and Growth of Residential Neighbourhoods in American Cities. Washington D.C. Federal Housing Administration.

[7] Harris, C., Ullman, E., 1945: The nature of cities. Annals of the American Academy of Political Science, 242, pp. 7-17.

[8] Jacyna M.: Modelowanie i ocena systemów transportowych. [Modelling and Assessment of Transport Systems], Oficyna Wydawnicza Politechniki Warszawskiej, Warszawa 2008.

[9] Matalewski M., Konecka S., Fajfer P., Wojciechowski A., Systemy logistyczne, komponenty, działania, przykłady [Logistic Systems, Components, Operations, Examples], Biblioteka Logistyka,Poznań 2008.

[10] Schäffeler, U. Summary of Projects and Results from Topic Inner Urban Freight Transport and City Logistics,2003, www.eu-portal.net

[11] Słodczyk J.: Przestrzeń miasta i jej przeobrażenia [The Urban Space and its Transformations], University of Opole, Opole 2003.

[12] Szołtysek J., Podstawy logistyki miejskiej [Rudiments of Urban Logistics], Wydawnictwo Akademii Ekonomicznej, Katowice 2000.

[13] Tundys B.: Logistyka miejska, [Urban Logistics] Wydawnictwo Difin, Warszawa 2008.

[14] Chief Statistical Office, www.stat.gov.pl

[15] Report from Task 3 entitled Position of Urban Logistics in the Domestic Logistic System. Development Project on: The Model of the Logistic System of Poland as a Way to Transport Comodality in the European Union. 